\title{
Introducing Lean Six Sigma to a German Municipality: an Action Research Report
}

This is the author's version of a work that was accepted for publication in the following source:

Kregel, I. and Coners, A. (2018), "Introducing lean six sigma to a German municipality: an action research report”, International Journal of Lean Six Sigma, Vol. 9 No. 2, pp. 221-237.

C) Emerald Publishing Limited 2018

\section{Notice:}

Changes introduced as a result of publishing processes such as copy-editing and formatting may not be reflected in this document. For a definitive version of this work, please refer to the published source:

https://doi.org/10.1108/IJLSS-02-2017-0019 


\title{
INTRODUCING LEAN SIX SigMA TO A GERMAN MUNICIPALITY: AN ACTION RESEARCH REPORT
}

\author{
Research paper
}

\section{Purpose}

This research aims to expand the knowledge about Lean Six Sigma (LSS) implementation in the public sector. By analyzing an LSS improvement initiative in a German municipality, examples of success, barriers and challenges are discussed. A comparison with literature regarding the production and service sectors unfolds similarities and differences.

\section{Design/methodology/approach}

The paper applies the action research method. Especially for the broad field of project management, methods focusing on actual experience from practice have been recommended by many researchers.

\section{Findings}

Implementations of LSS in the public sector seem to be particularly challenging and lengthy. Change and communication management have proved to be the most important aspects to successful acceptance, cooperation and improvement sustainability. In the analyzed cases, the needed volume of data could often not be procured. The applied Six Sigma methodology primarily included the DMAIC project phases as well as selected standard instruments. In contrast, the lean elements of LSS achieved more results and were appreciated by project team members.

\section{Originality/value}

The LSS application in this article provides insights into practical implementation experience in a municipality as well as lessons learned. Until now, most research addressed the single application of lean, continuous improvement or Six Sigma. This paper represents the first academic report of a LSS program in a German municipality and underlines the need for scientific support of those initiatives in further municipalities worldwide.

Keywords: Lean Six Sigma, Public Administration, Municipality, Local Government, Action Research, Case Study 


\section{$1 \quad$ Introduction}

Lean Six Sigma (LSS) is used by a large number of organizations worldwide to implement programs for business process performance improvement and cost reduction (Swink and Jacobs, 2012). Coming from manufacturing industries, both Lean and Six Sigma have also been applied to the service sector (Antony, 2006, 2011). Relative to this development, the public sector must still catch up with the private sector, but some inroads in applying LSS have already been made (Dewhurst et al., 1999; Radnor, 2010; Radnor and Walley, 2008; Radnor and Osborne, 2013).

This paper presents an action research case study about a German municipality of approximately 190,000 citizens. The first 2.5 years of an ongoing Lean Six Sigma introduction are analyzed to show developments over time as well as lessons learned. Furthermore, the collaboration between a university and a municipality represents an example how researchers and students can apply taught methods and tools in practice. The main goal is to provide insights for researchers and practitioners on how to implement the approach in a local government setting. To achieve this goal, the following research questions will be answered.

- RQ1: How can Lean Six Sigma be applied in a municipality?

- RQ2: Which methods and tools from LSS are best suited for this application area?

This article is structured as follows. After clarifying the research background of Lean Six Sigma and process improvement in the public sector, we present action research as the chosen research method. In the result section, we introduce the initial situation as well as the key elements of program management through the initiative. We build up a common understanding of characteristics and possibilities within the municipality by comparing the methods and tools of the different analyzed improvement projects. Based on these results, four main aspects influencing LSS in the municipality will be summarized before stating limitations and further research.

\section{$2 \quad$ Research Background}

\subsection{Process Improvement in the Public Sector}

Sreedharan and Raju (2016) list 46 published definitions and statements in order to achieve a common view on Lean Six Sigma. It is generally agreed, that Lean Six Sigma is the combination of Lean Management or the Lean Philosophy and Six Sigma (Arnheiter and Maleyeff, 2005; Näslund, 2008; Maleyeff et al., 2012). Snee (2010) defines it as "a business strategy and methodology that increases process performance resulting in enhanced customer satisfaction and improved bottom line results." It 
has to be distinguished from the popular concept of continuous improvement (CI) or "Kaizen" as introduced by Masaaki Imai (1986). His general concept of "change to a better state" has been defined by Brunet and New (2003) "to consist of pervasive and continual activities, outside the contributor's explicit contractual roles, to identify and achieve outcomes he believes contribute to the organizational goals." The main difference to Lean Six Sigma projects is the "mass involvement in making relatively small changes [...] on an ongoing basis" (Caffyn, 1999). In contrast to LSS, continuous improvement initiatives can be found in the public sector in many variations (Suarez Barraza et al., 2009; Fryer and Ogden, 2014).

Lean Six Sigma not only has a process background but is also known as one of the most prominent quality philosophies. The extensive application of Six Sigma quality management initiatives has been very successful in the manufacturing as well as the service industries (Eriksson, 2016; Patyal and Koilakuntla, 2017). Scientific literature about Lean and Six Sigma in the public sector can be found, for example, for healthcare (Taner et al., 2007; Antony et al., 2007b) and higher education (Antony et al., 2012; Thomas et al., 2015; Douglas et al., 2015; Svensson et al., 2015). In local government institutions, Lean Six Sigma has been tested, but has not been widely disseminated (Furterer and Elshennawy, 2007; Jonsson et al., 2011; Antony and Karaminas, 2016).

The public sector has undergone major transformations during the last decades in many countries (Wollmann, 2004). Starting in the 1980s, the New Public Management (Hood, 1991; Hood and Lodge, 2004) was one of the main philosophies to modernize government institutions and integrate ideas from private sector practice. These transformations also had a direct impact on German organizations (Kuhlmann et al., 2008). Still, considerable differences in culture and professional process improvement exist between the private and public sectors (Gulledge and Sommer, 2002). One of the specific characteristics discussed for public services is the question about the processes' customers and how to define the respective effective quality (Swiss, 1992; Fryer et al., 2007; Elg et al., 2015). Government organizations have to consider both internal and external demands on their processes. Many divisions of a municipality have direct contact to citizens or companies and should align their processes and service standards on the customer demand (Osborne et al., 2013).

Based on this theoretical foundation, we started LSS projects focusing on methods and tools from service sector applications (Heckl et al., 2010). In our research project, we used Lean Six Sigma to provide methods and tools from Lean Management and Six Sigma. All LSS projects have been set up to use the DMAIC project phases from Six Sigma as the main structure and to use tollgate reviews after each phase to ensure consensus about the project progress by project managers, coach and champion. Only a few methods and tools have been determined as obligatory. Examples are the short process summary 
"SIPOC" and the voice of the customer (VoC). With respect to most parts of the projects, the managers have been free in choosing the best-fitting LSS elements for the project's progress.

\subsection{Method}

The article presents an approach for gaining knowledge not only by observing and analyzing, but also by influencing and cooperating with the research subject (Gummesson, 2000). Therefore, instead of classical case study research, this report comprises results from action research (Susman and Evered, 1978; Benbasat et al., 1987; Coghlan, 2011). Action research can be defined as an "evolving process that is undertaken in a spirit of collaboration and co-inquiry. [...] It is simultaneously concerned with bringing about change in organizations, in developing self-help competencies in organizational members and adding to scientific knowledge" (Shani and Pasmore, 1985, p. 439). This break of neutrality and pure external view is the subject of controversial debates (Eden and Huxham, 1996; Avison et al., 1999; Wicks and Reason, 2009). We applied the action research concept to the municipality by starting a Lean Six Sigma program in order to analyze its applicability in this novel environment. While trainings employees and students, coaching projects and spreading the philosophy, methods and tools of LSS, we simultaneously influenced and researched the programs progress as the results section will show in detail.

The collaboration characteristics of the presented case support several recommended factors from the British Journal of Management's special issue "Impact and Management Research" from 2017 (MacIntosh et al., 2017). According to the authors, the relationship between research and praxis as well as between students and teachers should be strengthened to achieve a greater impact of management research upon the economy (Anderson et al., 2017; Cunliffe and Scaratti, 2017). The perennial cooperation between university and municipality ("longitudinal immersion") and furthermore the continuous coaching of the student project leaders enables an "extensive engaged scholarship" as proposed by Wells and Nieuwenhuis (2017).

The application of Lean Six Sigma to improve process performance is part of the field of operations management (Voss et al., 2002; Linderman et al., 2003; Schroeder et al., 2008; Zu et al., 2008). Researchers in this field encourage their colleagues to apply action research to gain knowledge directly within and in cooperation with companies to enrich the body of research knowledge (McCutcheon and Meredith, 1993; Meredith, 1998; Voss et al., 2002; Stuart et al., 2002; Coughlan and Coghlan, 2002). Insofar as Lean Six Sigma focuses on business processes, the field of business process management is also applicable (Paim et al., 2008; Sidorova and Isik, 2010). Houy et al. (2010) analyze trends in BPM 
publications. According to their analysis of five main research methods, action research has only been applied in 7 out of $355 \mathrm{bpm}$ publications from 1992 to 2008.

As a third aspect of Lean Six Sigma applications, we consider the discipline of project management, and answer the call of Cicmil et al. (2006) for more "actuality research" in this discipline. Project management research has often been criticized as being too instrumental or functionalistic (Packendorff, 1995; Hodgson, 2002; Winter et al., 2006). In this regard, Söderlund (2004) describes distinct differences between the engineering and social science traditions and their views on project management. In this article, the actually applied methods and tools of three LSS projects in a municipality will be described along with experienced success and failure factors within the initiative to summarize lessons learned (Schindler and Eppler, 2003).

\section{Results}

\subsection{Initial Situation}

The initial situation of the investigated city offered large potential for improvement. The debt per capita was one of the highest within Germany. Due to budget cuts, the number of personnel had to be decreased significantly within only a few years. Therefore, the so called "burning platform" as a beneficial precondition for substantial change existed (Bitner and Brown, 2008). On the other hand, the negative development of the municipality's financial situation as well as a hiring freeze led to dissatisfaction on the part of employees. To make matters worse, current challenges for municipalities in Germany like digitalization and innovative citizen demands circumvent pure cost-cutting and retreat arrangements (Dunleavy et al., 2006; Ashworth et al., 2013; Greve, 2015).

In 2014, a joint interest group for operational excellence (Basu, 2004) was founded, consisting of the local university of applied sciences, the municipality and two regional companies which were already using Lean Management and, in part, Six Sigma. The aim was to transfer knowledge between the partners by discussing typical challenges as well as process improvement development in the respective organizations. For the next years, student projects and coaching by the university's faculty were slated to become the keystone of the cooperation. Workshops with regional companies and joint employee trainings expanded the knowledge exchange.

\subsection{Deployment of Lean Six Sigma}

Within the first 2.5 years, three student projects were implemented, each lasting six months. At the local university of applied sciences, most of the bachelor's and master's theses are the result of cooperation 
with a company or public organization on a concrete problem or challenge. This cooperative work is subsequently combined with the scientific background of the thesis. The first project at the municipality was executed by two bachelor students who had only basic LSS yellow belt knowledge through a process management course. The organizational department was the responsible unit to provide the project managers with knowledge and support about the municipality's structures and procedures and acted as daily mentors. A project coach from the university trained the students especially during the first half of the project's duration to provide them with knowledge of the Green Belt (GB) level as training on the job.

During that time, a new major in the master's program of industrial engineering was created. As a result, students could also take two new courses about Lean Management and Six Sigma and receive a certificate of attendance for the theoretical knowledge of a Lean Six Sigma Green Belt. To achieve a commonly accepted GB certificate, students had to submit the documentation of a real DMAIC project, including the correct handling of all five project phases. Some students of the LSS courses utilized their master's thesis projects to execute process improvement projects in companies. In these cases, they could contact the faculty and receive support in form of coaching and tollgate reviews. The cooperation with the municipality was only one of the possibilities for the students, but it also enabled the most intense supervision due to the research partnership between the local government and university. The second project's team consisted of one trained GB from the master course and one bachelor student who learned the details of LSS on the job. The feedback about this model was more positive than on the first one. For the third project, two master students with GB knowledge and curiosity for process management in public administration could be found. This variant turned out to be the most successful one, as the first weeks could immediately be used start into project work.

After the first explorative steps, the question of scope and goals of the cooperation had to be answered anew (van der Hoorn, 2016). A few pilot projects can bring new insights and (hopefully) success stories to an organization, but would never be able to significantly change its culture and move it towards the goals of operational excellence (Fernandez and Rainey, 2006; Chakravorty, 2009). After the first year, an LSS GB training was provided for the municipality, open for volunteers from all city departments. Unfortunately, the idea of starting several de-centralized projects turned out to be too optimistic. When asked later about the concrete results of the attended training, many participants listed limited time and resources as the main reasons for not starting their own DMAIC projects. Nevertheless, many participants found the numerous methods and tools discussed to be useful in daily work life and middle management tasks, such as weekly group meetings and problem-solving workshops. 
As a reaction to this development, a new central unit of four process project managers was founded within the municipality. In addition to the ongoing student projects, these managers were to pursue further projects and enlarge the overall impact of the LSS initiative. To train these new project managers and to widen the number of Green Belts within the organization in general, a second GB training was held. For the future, the municipality plans further student projects. Additionally, Yellow Belt trainings are planned to be held by own employees to enlarge the knowledge of Lean Six Sigma and enable better support and acceptance from the affected personnel. The dependence on the university should be reduced successively while spreading the LSS knowledge and training within the organization.

\subsection{Analysis of applied LSS tools and methods}

The three executed projects lasted six months each and took place in different organizational units. Table 1 summarizes key information from them. One of the common challenges for the projects was the scarcity of data for extensive data analysis corresponding to the Six Sigma approach. Additionally, the organizational resistance against significant change turned out to be higher than anticipated. Two projects which focused on the processes of single organizational units surprisingly experienced more resistance and, ultimately, fewer project benefits than the one with cross-departmental collaboration and, as a result, higher complexity.

\begin{tabular}{|l|c|c|c|c|}
\hline Project Scope & $\begin{array}{l}\text { Available } \\
\text { Data }\end{array}$ & $\begin{array}{l}\text { Project } \\
\text { Complexity }\end{array}$ & $\begin{array}{l}\text { Project } \\
\text { Benefits }\end{array}$ & $\begin{array}{l}\text { Organizational } \\
\text { Resistance }\end{array}$ \\
\hline $\begin{array}{l}\text { Processes of the customer office for land } \\
\text { acquisition and building construction }\end{array}$ & Low & Low & Low & High \\
\hline $\begin{array}{l}\text { Subsidy application and administration } \\
\text { processes (cross-departmental) }\end{array}$ & Low & High & High & Medium \\
\hline Business registration office processes & Low & Low & Low & High \\
\hline
\end{tabular}

Table 1: Main Characteristics of Student Projects

We will describe the methods and tools used in the projects in the following sections, and we will summarize them chronologically in tables 2-6. The use of a tool or method is indicated in the chart by either $\mathrm{a}+$ or - ; information in brackets provides specific details on some entries.

The Define phases containing the first steps of each project were all structured similarly. The individual characters of the projects became more distinct in the following phases. The first kick-off workshop resulted in confusion between the organization department and students on the one side and the investigated department on the other. Important preconditions had been interpreted differently, and the project was threatened with failure. Projects two and three took this experience into account by preparing the Define phase even more extensively and expanding the communication planning and effort. The proportion of stakeholder management and communication increased at the expense of direct work on 
tools and methods, but it was valued as an important investment in project team and affected employee acceptance (Fisher, 2011; Elias, 2016b; Parker et al., 2017). According to systems thinking, stakeholder management has to consider internal and external parties and align the processes to optimally work within this system (Elias, 2016a). Relating to this challenge, formulating the voice of the customer (VOC) and deriving critical-to-quality (CTQ) indicators were the largest methodological challenges during the Define phase. The students of all three projects needed several drafts and coaching advice until they could pass the define tollgate. The identification of the correct customers for the processes in public administration as well as identifying concrete indicators and target values proved to be difficult steps (Bryson, 2004).

\begin{tabular}{|l|c|c|c|}
\hline Method / Tool & Used in Project 1 & Used in Project 2 & Used in Project 3 \\
\hline $\begin{array}{l}\text { Project Charter } \\
\text { / Scoping Workshop }\end{array}$ & + / & $+/-$ & $+/+$ \\
\hline Project Vision & - & + & - \\
\hline Kick-off Workshop & $+($ fail $)$ & - & + (success) \\
\hline $\begin{array}{l}\text { Stakeholder Analysis } \\
\text { / Development Plan }\end{array}$ & + / & $+/-$ & $+/+$ \\
\hline Communication Plan & + & + & + \\
\hline SIPOC & $+(3)$ & $+(2)$ & $+(1)$ \\
\hline VOC / VOB & $+/+$ & $-/+$ & $+/+$ \\
\hline CTQ & + & + & + \\
\hline $\begin{array}{l}\text { Check of Competitors } \\
\text { (municipalities) }\end{array}$ & + & + & + \\
\hline Quick Wins & - & - & + \\
\hline Tollgate Define & + & + & + \\
\hline
\end{tabular}

Table 2: Content Comparison of the Projects' Define Phase

Interviews with the process-related employees to learn about the process details were a key element of the Measure phase. The processes were then modeled by using standard flow charts, event-driven process chains (EPC), and the semantic process modeling language, PICTURE, which was developed especially for the public sector (Becker et al., 2007; Becker et al., 2015) and had been acquired by the municipality before the initiative started. One project extended the personal impressions about the employee's process satisfaction by a short survey to identify the most critical process steps and reservations. As the following table 3 shows, the third project went into greater detail with respect to finding the most important process indicators. After creating an Ishikawa diagram (Ishikawa, 1985) with their project team, they prepared the measuring by creating operational definitions. Still, the amount of data was not higher than during the two previous projects and more detailed Six Sigma methods like the measurement system analysis would not have been helpful in this project environment. 


\begin{tabular}{|c|c|c|c|}
\hline Method / Tool & Used in Project 1 & Used in Project 2 & Used in Project 3 \\
\hline Staff Interviews & + & + & + \\
\hline $\begin{array}{l}\text { Process Modeling } \\
\text { (Methods) }\end{array}$ & $\begin{array}{c}+ \text { (Flow Charts \& } \\
\text { PICTURE BPMN) }\end{array}$ & $\begin{array}{c}+(\text { EPC \& } \\
\text { PICTURE BPMN })\end{array}$ & $\begin{array}{c}+ \\
(\text { PICTURE BPMN) }\end{array}$ \\
\hline $\begin{array}{l}\text { Employee Process } \\
\text { Satisfaction Analysis }\end{array}$ & - & + & - \\
\hline $\begin{array}{l}\text { Performance Indicator } \\
\text { Brainstorming } \\
\text { (Ishikawa Diagram) }\end{array}$ & - & - & + \\
\hline Process Indicator Analysis & - & - & + \\
\hline Operational Definitions & - & - & + \\
\hline Data Collection Plan & + & + & + \\
\hline $\begin{array}{l}\text { Process Volume Analysis } \\
\text { (Discrete Data) }\end{array}$ & + & + & + \\
\hline Process Variant Analysis & + & - & + \\
\hline As-Is Performance Check & + & + & + \\
\hline Tollgate Measure & + & + & + \\
\hline
\end{tabular}

Table 3: Content Comparison of the Projects' Measure Phase

Relating to the creation of process models and scarcity of detailed data, the added value analysis was an important tool to identify spots for improvement. At the same time, the process analysis for the eight types of waste corresponding to the Lean philosophy was executed (Womack et al., 1991; Womack and Jones, 2003; Thürer et al., 2017). For the administrative processes, the flow of information proved to be more important to analyze and change than the material flow. The choice of methods and tools shows that projects one and three were more similar to each other than to project two. The second project mainly analyzed the large subsidy application process through several units in detail, whereas the other projects included a many different processes belonging to the same organizational unit.

\begin{tabular}{|l|c|c|c|}
\hline Method / Tool & Used in Project 1 & Used in Project 2 & Used in Project 3 \\
\hline Added Value Analysis & + & + & + \\
\hline $\begin{array}{l}\text { Cause Brainstorming } \\
\text { (Ishikawa) }\end{array}$ & + & - & - \\
\hline $\begin{array}{l}\text { Systematic Process } \\
\text { Weakness Identification } \\
\text { (Process Models) }\end{array}$ & - & + & - \\
\hline $\begin{array}{l}\text { Process Object and } \\
\text { Information Flow Analysis }\end{array}$ & - & + & - \\
\hline $\begin{array}{l}\text { Customer Frequency and } \\
\text { Working Time Analysis }\end{array}$ & - & - & + \\
\hline $\begin{array}{l}\text { Office Layout Analysis } \\
\text { (Spaghetti Diagram) }\end{array}$ & + & - & + \\
\hline $\begin{array}{l}\text { Material Cost } \\
\text { Transparency }\end{array}$ & - & - & + \\
\hline
\end{tabular}




\begin{tabular}{|l|c|c|c|}
\hline $\begin{array}{l}\text { Workforce Utilization } \\
\text { Analysis (estimation) }\end{array}$ & - & - & + \\
\hline Root Cause Analysis & + & + & + \\
\hline Tollgate Analyze & + & + & + \\
\hline
\end{tabular}

Table 4: Content Comparison of the Projects' Analyze Phase

The ways of improvement again show more similarities among the projects. Many of their elements can be found in other case studies from business process improvement projects in administration and service processes (Furterer, 2009; Cudney et al., 2014). Characteristic for the student projects was that most of the improvement ideas could not be implemented during this phase but had to be formally confirmed and ordered by the respective manager after the final presentation. This course of action implies a higher risk of subsequent non-implementation and contravenes the Six Sigma approach. For extensive changes, this separation can also be found in the private sector. For smaller changes though, it was only accepted due to the externality of the project leaders and the pilot character of the projects.

\begin{tabular}{|l|c|c|c|}
\hline Method / Tool & Used in Project 1 & Used in Project 2 & Used in Project 3 \\
\hline $\begin{array}{l}\text { Task and Responsibilities } \\
\text { Reallocation }\end{array}$ & + & + & - \\
\hline $\begin{array}{l}\text { Process Interface Redesign } \\
\text { (Information Flow) }\end{array}$ & + & + & - \\
\hline $\begin{array}{l}\text { Digitization of (some) } \\
\text { business documents }\end{array}$ & + & + & - \\
\hline $\begin{array}{l}\text { Process IT support } \\
\text { enhancement }\end{array}$ & + & + & - \\
\hline $\begin{array}{l}\text { Office Layout Redesign } \\
\text { Fundamental Process }\end{array}$ & + & - & + \\
\hline Influence Factor Analysis & + & - & + \\
\hline $\begin{array}{l}\text { Website's Content and } \\
\text { Structure Revision }\end{array}$ & + & - & + \\
\hline $\begin{array}{l}\text { 5S Pilot Execution }+ \\
\text { Sustainability Plan }\end{array}$ & - & - & + \\
\hline Process Checklist Creation & - & - & - \\
\hline $\begin{array}{l}\text { Root Cause / Solution } \\
\text { Matrix }\end{array}$ & - & + & + \\
\hline Implementation Plan & + & + & + \\
\hline Tollgate Improve & + & - & + \\
\hline
\end{tabular}

Table 5: Content Comparison of the Projects' Improve Phase

For the students, the last DMAIC phase represented a time for summing up the project, preparing the important final presentation for the city council, and, in some cases, already working on the degree theses. The installation of sustainable performance measurement systems to uphold a higher standard of process performance was attempted but depends to a large degree upon the individual manager's own 
conviction and even more on the overall organization's performance system (Radnor and Pidd, 2005). For many managers, the calculated project benefits are the most interesting element of the Control phase. Due to high change resistance and uncertain degrees of idea implementation, the benefits of projects one and three were on the scale of a few thousand Euros. The second project, however, gained enormous public attention when one of the students continued his project work afterwards as a temporary employee and applied the developed process improvements and standards for a large funding application. With more than five million Euros, the municipality received a very large part of a subsidy and celebrated a major success.

\begin{tabular}{|l|c|c|c|}
\hline Method / Tool & Used in Project 1 & Used in Project 2 & Used in Project 3 \\
\hline $\begin{array}{l}\text { Indicator-based Process } \\
\text { Steering Concept and } \\
\text { Dashboard Draft }\end{array}$ & - & - & + \\
\hline $\begin{array}{l}\text { Process Documentation } \\
\text { (new state) }\end{array}$ & + & + & + \\
\hline \begin{tabular}{l|l|} 
Project Benefit Calculation \\
Project Documentation
\end{tabular} & + & + & + \\
\hline $\begin{array}{l}\text { Project Handover to } \\
\text { Department }\end{array}$ & + & + & + \\
\hline Lessons Learned & + & + & + \\
\hline Final Presentation & + & + & + \\
\hline Tollgate Control & + & + & + \\
\hline
\end{tabular}

Table 6: Content Comparison of the Projects' Control Phase

\section{$4 \quad$ Discussion and Conclusion}

To structure the following discussion, we follow related success factor analyses from the literature. The results of a study by Heckl et al. (2010) about Six Sigma in the financial sector have proved to be very similar to those of the documented municipality case. In addition, three publications about success and failure factors for (Lean) Six Sigma programs have been taken into account (Coronado and Antony, 2002; Antony and Banuelas, 2002; Albliwi et al., 2014):

\section{Organizational Culture and Fear of Change}

When we evaluated the past projects with the program coordinators, the influence of the organizational culture and the resistance against change was ranked very high. In the literature, process-orientation is recommended in order to increase the organizational performance independently from the particular economic sector (Hung, 2006; Hellström and Eriksson, 2013). Researchers agree on the high influence of culture on the processes and their performance (Sackmann, 1992; Schneider et al., 1995). With focus 
on business processes, Schmiedel et al. $(2013,2014)$ describe a method to measure the degree of process culture within an organization. A specific analysis of process culture for local governments cannot be found in the literature. Desirable cultural characteristics regarding the Lean Management philosophy however have been published by several authors (Liker, 2004; Liker and Hoseus, 2008; Angelis et al., 2011; Losonci et al., 2017). Furthermore, the organizational culture has also been shown to have a significant influence to the success of Six Sigma and the related Total Quality Management (McNabb and Sepic, 1995; Dahlgaard and Dahlgaard-Park, 2006).

The importance of change management, communication and active stakeholder management gained more attention during the program and turned out to be significantly important in local government (Ferlie et al., 2003; Kim, 2012; Kuipers et al., 2014). An idea on how to lower the barrier between beginners and the complex and new Lean Six Sigma method was to customize the training material for the municipality. The GB training was already focused on service processes and enriched by a few examples from the municipality's projects; but for the new training, the level of recognition and adaptability should be increased again. The idea of creating alternatives for technical and English terms like SIPOC, VOC, CTQ etc. was discussed but was finally rejected in favor of upholding international standards.

The overarching factor in overcoming culture and change challenges, however, is time. If the municipality proves its perseverance, more projects can be launched, more employees trained and the pervasion of method and philosophy of Lean Six Sigma will be fostered (Arumugam et al., 2016). A large impact in sustaining the LSS philosophy within the organization comes from continuous management support, which has been identified as another main influencing factor.

\section{(Top) Management Support}

The mayor as the top manager of the municipality was one of the main supporters of the whole Lean Six Sigma initiative. For successful change implementations though, all levels of managers have to be included and become active (Laureani and Antony, 2015, 2018a, 2018b). Regarding this aspect, very different experiences were noted in the municipality. Some managers acted either neutrally or even as obstacles to the projects, though they had previously been the project champions. Some seemed to fear that improvement potential discovered in the course of the projects could expose substandard work of theirs from the past. To work on the role of leadership and application of new leadership approaches, a second professor was consulted who is specialized in this field. With the help of an employee survey and first leadership discussion workshops, a change in leadership could be achieved in the future (Valle, 1999; Suresh et al., 2012). 


\section{Data Availability}

For a successful Lean project, data does not necessarily have to be available. However, the classical Six Sigma approach relies heavily on data and its careful analysis. The projects followed the DMAIC phases and used many Six Sigma tools, but data within the municipality could have been much more readily available. Most of the data included only quantity statistics. Especially the existence or creation of data with respect to processing times was nearly impossible. The importance of labor and privacy protection as well as the predominance of the staff council are higher than in the private sector and prevented or restricted the data analysis in some cases.

\section{Project Identification and Selection}

The projects were identified by the organizational department and selected together with the program coaches. For the first two projects, the number of choices was very limited and more options could only be managed by changing the scope of the project. For the third project and from that time on, a list of project candidates was maintained to choose new projects by several decision aspects and their individual weighting (Kumar et al., 2009; Adebanjo et al., 2016).

Not only must the right project topic and place be selected, but the choice of the project leader can have a high influence on the success of projects as well (Nair et al., 2011). Inherited from Six Sigma, Green and Black Belt trainings and knowledge levels exist to train candidates in tools and methods to lead appropriate projects. To choose the right candidates for these trainings, researchers have identified competencies that are in particular demand (Antony et al., 2007a; Antony and Karaminas, 2016).

\section{$5 \quad$ Limitations and Further Research}

This article presents examples how Lean Six Sigma has been applied to a municipality. Besides methods how to spread the philosophy within the organization, three pilot projects have been discussed in detail. The analysis of used methods and tools can help researchers and practitioners to understand which parts of the methodology are more or less suited for the public sector.

The documented experiences were influenced by the work of the researchers insofar as this is part of the action research method. Furthermore, three projects and two Green Belt trainings cannot result either in a comprehensive change of organizational culture or the achievement of a high degree of operational excellence (Barney, 1986; Irani et al., 2004; McNulty and Ferlie, 2004). Experience and endurance are very important factors for LSS projects and program success (Easton and Rosenzweig, 2012). The city will have to learn from its projects and widen the scope and variety of projects in order to gain more experience and acceptance of improvement projects (Arumugam et al., 2013). 
As a main limitation, this action research report focuses on only one municipality in one country. To maintain a common understanding about Lean Six Sigma in local governments, a large number of cases has to be collected and analyzed. As governmental processes are highly influenced by laws and regulations, larger differences between countries can be expected. On the other hand, government processes are a subgroup of administration and service processes and are, thus, people-intensive relative to manufacturing processes (Robertson and Seneviratne, 1995). Therefore, many similarities even among different countries can be expected, too.

\section{$6 \quad$ References}

Adebanjo, D., Samaranayake, P., Mafakheri, F. and Laosirihongthong, T. (2016), "Prioritization of Six-Sigma project selection", Benchmarking: An International Journal, Vol. 23 No. 7, pp. 19832003.

Albliwi, S., Antony, J., Abdul Halim Lim, S. and van der Wiele, T. (2014), "Critical failure factors of Lean Six Sigma. A systematic literature review", International Journal of Quality \& Reliability Management, Vol. 31 No. 9, pp. 1012-1030.

Anderson, L., Ellwood, P. and Coleman, C. (2017), “The Impactful Academic. Relational Management Education as an Intervention for Impact", British Journal of Management, Vol. 28 No. 1, pp. 14-28.

Angelis, J., Conti, R., Cooper, C. and Gill, C. (2011), "Building a high-commitment lean culture", Journal of Manufacturing Technology Management, Vol. 22 No. 5, pp. 569-586.

Antony, J. (2006), "Six sigma for service processes", Business Process Management Journal, Vol. 12 No. 2, pp. 234-248.

Antony, J. (2011), "Six Sigma vs Lean. Some perspectives from leading academics and practitioners", International Journal of Productivity and Performance Management, Vol. 60 No. 2, pp. 185-190.

Antony, J. and Banuelas, R. (2002), "Key ingredients for the effective implementation of Six Sigma program", Measuring business excellence, Vol. 6 No. 4, pp. 20-27.

Antony, J., Douglas, A. and Antony, F.J. (2007a), "Determining the essential characteristics of Six Sigma Black Belts. Results from a pilot study in UK manufacturing companies", The TQM Magazine, Vol. 19 No. 3, pp. 274-281.

Antony, J. and Karaminas, H. (2016), "Critical assessment on the Six Sigma Black Belt roles/responsibilities, skills and training", International Journal of Quality \& Reliability Management, Vol. 33 No. 5, pp. 558-573.

Antony, J., Krishan, N., Cullen, D. and Kumar, M. (2012), "Lean Six Sigma for higher education institutions (HEIs). Challenges, barriers, success factors, tools/techniques", International Journal of Productivity and Performance Management, Vol. 61 No. 8, pp. 940-948.

Antony, J., Kumar, M. and Rae Cho, B. (2007b), "Six sigma in service organisations. Benefits, challenges and difficulties, common myths, empirical observations and success factors", International Journal of Quality \& Reliability Management, Vol. 24 No. 3, pp. 294-311.

Arnheiter, E.D. and Maleyeff, J. (2005), "The integration of lean management and Six Sigma", The TQM Magazine, Vol. 17 No. 1, pp. 5-18. 
Arumugam, V., Antony, J. and Kumar, M. (2013), "Linking learning and knowledge creation to project success in Six Sigma projects. An empirical investigation", International Journal of Production Economics, Vol. 141 No. 1, pp. 388-402.

Arumugam, V., Antony, J. and Linderman, K. (2016), "The influence of challenging goals and structured method on Six Sigma project performance. A mediated moderation analysis", European Journal of Operational Research, Vol. 254 No. 1, pp. 202-213.

Ashworth, R., Ferlie, E., Hammerschmid, G., Moon, M.J. and Reay, T. (2013), “Theorizing Contemporary Public Management. International and Comparative Perspectives", British Journal of Management, Vol. 24, S1-S17.

Avison, D.E., Lau, F., Myers, M.D. and Nielsen, P.A. (1999), “Action research”, Communications of the ACM, Vol. 42 No. 1, pp. 94-97.

Barney, J.B. (1986), "Organizational Culture. Can It Be a Source of Sustained Competitive Advantage?", Academy of Management Review, Vol. 11 No. 3, pp. 656-665.

Basu, R. (2004), "Six-Sigma to operational excellence. Role of tools and techniques", International Journal of Six Sigma and Competitive Advantage, Vol. 1 No. 1, pp. 44-64.

Becker, J., Algermissen, L., Pfeiffer, D. and Räckers, M. (2007), "Building block based modeling of process landscapes with the PICTURE approach - The example of Münster's University administration", Wirtschaftsinformatik, Vol. 49 No. 4, pp. 267-279.

Becker, J., Pfeiffer, D., Räckers, M., Falk, T. and Czerwonka, M. (2015), "Semantic Business Process Modelling and Analysis", in vom Brocke, J. and Rosemann, M. (Eds.), Handbook on Business Process Management 1: Introduction, Methods, and Information Systems, International handbooks on information systems, 2nd ed., Springer, Berlin Heidelberg, pp. 187-217.

Benbasat, I., Goldstein, D.K. and Mead, M. (1987), "The Case Research Strategy in Studies of Information Systems", MIS Quarterly, Vol. 11 No. 3, p. 369.

Bitner, M.J. and Brown, S.W. (2008), “The service imperative”, Business Horizons, Vol. 51 No. 1, pp. $39-46$.

Brunet, A.P. and New, S. (2003), "Kaizen in Japan. An empirical study", International Journal of Operations \& Production Management, Vol. 23 No. 12, pp. 1426-1446.

Bryson, J.M. (2004), "What to do when Stakeholders matter. Stakeholder Identification and Analysis Techniques", Public Management Review, Vol. 6 No. 1, pp. 21-53.

Caffyn, S. (1999), "Development of a continuous improvement self-assessment tool”, International Journal of Operations \& Production Management, Vol. 19 No. 11, pp. 1138-1153.

Chakravorty, S.S. (2009), "Six Sigma programs. An implementation model”, International Journal of Production Economics, Vol. 119 No. 1, pp. 1-16.

Cicmil, S., Williams, T., Thomas, J. and Hodgson, D. (2006), "Rethinking Project Management. Researching the actuality of projects", International Journal of Project Management, Vol. 24 No. 8, pp. 675-686.

Coghlan, D. (2011), “Action Research: Exploring Perspectives on a Philosophy of Practical Knowing", The Academy of Management Annals, Vol. 5 No. 1, pp. 53-87.

Coronado, R.B. and Antony, J. (2002), "Critical success factors for the successful implementation of six sigma projects in organisations", The TQM Magazine, Vol. 14 No. 2, pp. 92-99.

Coughlan, P. and Coghlan, D. (2002), "Action research for operations management", International Journal of Operations \& Production Management, Vol. 22 No. 2, pp. 220-240. 
Cudney, E.A., Furterer, S.L. and Dietrich, D.M. (Eds.) (2014), Lean systems: Applications and case studies in manufacturing, service, and healthcare, CRC Press, Boca Raton, FL, USA.

Cunliffe, A.L. and Scaratti, G. (2017), "Embedding Impact in Engaged Research. Developing Socially Useful Knowledge through Dialogical Sensemaking", British Journal of Management, Vol. 28 No. 1, pp. 29-44.

Dahlgaard, J.J. and Dahlgaard-Park, S.M. (2006), "Lean production, six sigma quality, TQM and company culture", The TQM Magazine, Vol. 18 No. 3, pp. 263-281.

Dewhurst, F., Martínez-Lorente, A.R. and Dale, B.G. (1999), "TQM in public organisations. An examination of the issues", Managing Service Quality: An International Journal, Vol. 9 No. 4, pp. $265-274$.

Douglas, J., Antony, J. and Douglas, A. (2015), "Waste identification and elimination in HEIs. The role of Lean thinking", International Journal of Quality \& Reliability Management, Vol. 32 No. 9, pp. 970-981.

Dunleavy, P., Margetts, H., Bastow, S. and Tinkler, J. (2006), "New Public Management Is Dead. Long Live Digital-Era Governance", Journal of Public Administration Research and Theory, Vol. 16 No. 3, pp. 467-494.

Easton, G.S. and Rosenzweig, E.D. (2012), "The role of experience in six sigma project success. An empirical analysis of improvement projects", Journal of Operations Management, Vol. 30 No. 78, pp. 481-493.

Eden, C. and Huxham, C. (1996), “Action Research for Management Research”, British Journal of Management, Vol. 7 No. 1, pp. 75-86.

Elg, M., Wihlborg, E. and Örnerheim, M. (2015), "Public quality - for whom and how? Integrating public core values with quality management", Total Quality Management \& Business Excellence, Vol. 28 No. 3-4, pp. 379-389.

Elias, A.A. (2016a), "Analysing the stakes of stakeholders in research and development project management. A systems approach", $R \& D$ Management, Vol. 46 No. 4, pp. 749-760.

Elias, A.A. (2016b), "Stakeholder analysis for Lean Six Sigma project management", International Journal of Lean Six Sigma, Vol. 7 No. 4, pp. 394-405.

Eriksson, H. (2016), “Outcome of quality management practices”, International Journal of Quality \& Reliability Management, Vol. 33 No. 9, pp. 1394-1405.

Ferlie, E., Hartley, J. and Martin, S. (2003), "Changing Public Service Organizations. Current Perspectives and Future Prospects", British Journal of Management, Vol. 14 No. s1, S1-S14.

Fernandez, S. and Rainey, H.G. (2006), "Managing Successful Organizational Change in the Public Sector", Public Administration Review, Vol. 66 No. 2, pp. 168-176.

Fisher, E. (2011), "What practitioners consider to be the skills and behaviours of an effective people project manager", International Journal of Project Management, Vol. 29 No. 8, pp. 994-1002.

Fryer, K.J., Antony, J. and Douglas, A. (2007), "Critical success factors of continuous improvement in the public sector", The TQM Magazine, Vol. 19 No. 5, pp. 497-517.

Fryer, K.J. and Ogden, S.M. (2014), "Modelling continuous improvement maturity in the public sector. Key stages and indicators", Total Quality Management \& Business Excellence, Vol. 25 No. 9-10, pp. 1039-1053.

Furterer, S.L. (2009), Lean Six Sigma in service: Applications and case studies, CRC Press, Boca Raton. 
Furterer, S.L. and Elshennawy, A.K. (2007), "Implementation of TQM and lean Six Sigma tools in local government. A framework and a case study", Total Quality Management \& Business Excellence, Vol. 16 No. 10, pp. 1179-1191.

Greve, C. (2015), "Ideas in Public Management Reform for the 2010s. Digitalization, Value Creation and Involvement", Public Organization Review, Vol. 15 No. 1, pp. 49-65.

Gulledge, T.R. and Sommer, R.A. (2002), "Business process management. Public sector implications”, Business Process Management Journal, Vol. 8 No. 4, pp. 364-376.

Gummesson, E. (2000), Qualitative methods in management research, 2nd ed., Sage, Thousand Oaks, Calif.

Heckl, D., Moormann, J. and Rosemann, M. (2010), "Uptake and success factors of Six Sigma in the financial services industry", Business Process Management Journal, Vol. 16 No. 3, pp. 436-472.

Hellström, A. and Eriksson, H. (2013), "Among Fumblers, Talkers, Mappers and Organisers. Four applications of process orientation”, Total Quality Management \& Business Excellence, Vol. 24 No. 5-6, pp. 733-751.

Hodgson, D. (2002), "Disciplining the professional. The case of project management", Journal of Management Studies, Vol. 39 No. 6, pp. 803-821.

Hood, C. (1991), “A public management for all seasons?”, Public Administration, Vol. 69 No. 1, pp. 3-19.

Hood, C. and Lodge, M. (2004), "Competency, Bureaucracy, and Public Management Reform. A Comparative Analysis”, Governance, Vol. 17 No. 3, pp. 313-333.

Houy, C., Fettke, P. and Loos, P. (2010), "Empirical research in business process management analysis of an emerging field of research", Business Process Management Journal, Vol. 16 No. 4, pp. 619-661.

Hung, R.Y.-Y. (2006), "Business process management as competitive advantage. A review and empirical study", Total Quality Management \& Business Excellence, Vol. 17 No. 1, pp. 21-40.

Imai, M. (1986), Kaizen, the key to Japan's competitive success, Random House Business Division, New York.

Irani, Z., Beskese, A. and Love, P.E.D. (2004), "Total quality management and corporate culture. Constructs of organisational excellence", Technovation, Vol. 24 No. 8, pp. 643-650.

Ishikawa, K. (1985), What is total quality control?: The Japanese way, Prentice Hall, Englewood Cliffs, N.J.

Jonsson, P., Stentoft Arlbjørn, J., Vagn Freytag, P. and Haas, H. de (2011), "Service supply chain management. A survey of lean application in the municipal sector", International Journal of Physical Distribution \& Logistics Management, Vol. 41 No. 3, pp. 277-295.

Kim, S. (2012), "Does Person-Organization Fit Matter in the Public -Sector? Testing the Mediating Effect of Person-Organization Fit in the Relationship between Public Service Motivation and Work Attitudes", Public Administration Review, Vol. 72 No. 6, 830-840.

Kuhlmann, S., Bogumil, J. and Grohs, S. (2008), "Evaluating Administrative Modernization in German Local Governments. Success or Failure of the "New Steering Model"?", Public Administration Review, Vol. 68 No. 5, pp. 851-863.

Kuipers, B.S., Higgs, M., Kickert, W., Tummers, L., Grandia, J. and van der Voet, J. (2014), "The Management of Change in Public Organizations. A Literature Review", Public Administration, Vol. 92 No. 1, pp. 1-20. 
Kumar, M., Antony, J. and Rae Cho, B. (2009), "Project selection and its impact on the successful deployment of Six Sigma", Business Process Management Journal, Vol. 15 No. 5, pp. 669-686.

Laureani, A. and Antony, J. (2015), "Leadership characteristics for Lean Six Sigma", Total Quality Management \& Business Excellence, Vol. 28 No. 3-4, pp. 405-426.

Laureani, A. and Antony, J. (2018a), "Leadership - a critical success factor for the effective implementation of Lean Six Sigma", Total Quality Management \& Business Excellence, Vol. 29 No. 5-6, pp. 502-523.

Laureani, A. and Antony, J. (2018b), "Leadership and Lean Six Sigma. A systematic literature review”, Total Quality Management \& Business Excellence, pp. 1-29.

Liker, J.K. (2004), The Toyota way: Fourteen Management Principles from the World's Greatest Manufacturer, McGraw-Hill, New York.

Liker, J.K. and Hoseus, M. (2008), Toyota culture: The heart and soul of the Toyota way, McGrawHill, New York.

Linderman, K., Schroeder, R.G., Zaheer, S. and Choo, A.S. (2003), "Six Sigma. A goal-theoretic perspective", Journal of Operations Management, Vol. 21 No. 2, pp. 193-203.

Losonci, D., Kása, R., Demeter, K., Heidrich, B. and Jenei, I. (2017), "The impact of shop floor culture and subculture on lean production practices", International Journal of Operations \& Production Management, Vol. 37 No. 2, pp. 205-225.

MacIntosh, R., Beech, N., Bartunek, J., Mason, K., Cooke, B. and Denyer, D. (2017), "Impact and Management Research. Exploring Relationships between Temporality, Dialogue, Reflexivity and Praxis", British Journal of Management, Vol. 28 No. 1, pp. 3-13.

Maleyeff, J., Arnheiter, E.A. and Venkateswaran, V. (2012), "The continuing evolution of Lean Six Sigma", The TQM Journal, Vol. 24 No. 6, pp. 542-555.

McCutcheon, D.M. and Meredith, J.R. (1993), "Conducting case study research in operations management", Journal of Operations Management, Vol. 11 No. 3, pp. 239-256.

McNabb, D.E. and Sepic, F.T. (1995), "Culture, Climate, and Total Quality Management. Measuring Readiness for Change", Public Productivity \& Management Review, Vol. 18 No. 4, pp. 369-385.

McNulty, T. and Ferlie, E. (2004), "Process Transformation. Limitations to Radical Organizational Change within Public Service Organizations", Organization Studies, Vol. 25 No. 8, pp. 13891412 .

Meredith, J. (1998), "Building operations management theory through case and field research", Journal of Operations Management, Vol. 16 No. 4, pp. 441-454.

Nair, A., Malhotra, M.K. and Ahire, S.L. (2011), "Toward a theory of managing context in Six Sigma process-improvement projects. An action research investigation", Journal of Operations Management, Vol. 29 No. 5, pp. 529-548.

Näslund, D. (2008), “Lean, six sigma and lean sigma. Fads or real process improvement methods?", Business Process Management Journal, Vol. 14 No. 3, pp. 269-287.

Osborne, S.P., Radnor, Z. and Nasi, G. (2013), “A New Theory for Public Service Management? Toward a (Public) Service-Dominant Approach”, The American Review of Public Administration, Vol. 43 No. 2, pp. 135-158.

Packendorff, J. (1995), "Inquiring into the temporary organization. New directions for project management research", Scandinavian Journal of Management, Vol. 11 No. 4, pp. 319-333. 
Paim, R., Mansur Caulliraux, H. and Cardoso, R. (2008), "Process management tasks. A conceptual and practical view", Business Process Management Journal, Vol. 14 No. 5, pp. 694-723.

Parker, D.W., Kunde, R. and Zeppetella, L. (2017), "Exploring communication in project-based interventions", International Journal of Productivity and Performance Management, Vol. 66 No. 2, pp. 146-179.

Patyal, V.S. and Koilakuntla, M. (2017), "The impact of quality management practices on performance. An empirical study”, Benchmarking: An International Journal, Vol. 24 No. 2, pp. $511-535$.

Radnor, Z. and Osborne, S.P. (2013), "Lean: A failed theory for public services?", Public Management Review, Vol. 15 No. 2, pp. 265-287.

Radnor, Z. and Pidd, M. (2005), "Perversity in public service performance measurement", International Journal of Productivity and Performance Management, Vol. 54 No. 5/6, pp. 482493.

Radnor, Z. and Walley, P. (2008), "Learning to Walk Before We Try to Run. Adapting Lean for the Public Sector”, Public Money \& Management, Vol. 28 No. 1, pp. 13-20.

Radnor, Z.J. (2010), Review of business process improvement methodologies in public services, AIM Research, London.

Robertson, P.J. and Seneviratne, S.J. (1995), "Outcomes of Planned Organizational Change in the Public Sector. A Meta-Analytic Comparison to the Private Sector", Public Administration Review, Vol. 55 No. 6, p. 547.

Sackmann, S.A. (1992), "Culture and Subcultures. An Analysis of Organizational Knowledge", Administrative Science Quarterly, Vol. 37 No. 1, p. 140.

Schindler, M. and Eppler, M.J. (2003), "Harvesting project knowledge. A review of project learning methods and success factors", International Journal of Project Management, Vol. 21 No. 3, pp. 219-228.

Schmiedel, T., vom Brocke, J. and Recker, J. (2013), "Which cultural values matter to business process management? Results from a global Delphi study", Business Process Management Journal, Vol. 19 No. 2, pp. 292-317.

Schmiedel, T., vom Brocke, J. and Recker, J. (2014), "Development and validation of an instrument to measure organizational cultures' support of Business Process Management”, Information \& Management, Vol. 51 No. 1, pp. 43-56.

Schneider, B., Goldstein, H.W. and Smith, D.B. (1995), "The ASA Framework. An Update", Personnel Psychology, Vol. 48 No. 4, pp. 747-773.

Schroeder, R.G., Linderman, K., Liedtke, C. and Choo, A.S. (2008), "Six Sigma. Definition and underlying theory", Journal of Operations Management, Vol. 26 No. 4, pp. 536-554.

Shani, A.B. and Pasmore, W. (1985), "Organisation inquiry. Towards a new model of the action research process", in Warrick, D.D. (Ed.), Contemporary organization development: Current thinking and applications, Scott, Foresman and Co, Glenview, Ill., p. 439.

Sidorova, A. and Isik, O. (2010), "Business process research. A cross-disciplinary review", Business Process Management Journal, Vol. 16 No. 4, pp. 566-597.

Snee, R.D. (2010), "Lean Six Sigma - getting better all the time", International Journal of Lean Six Sigma, Vol. 1 No. 1, pp. 9-29. 
Söderlund, J. (2004), "Building theories of project management. Past research, questions for the future", International Journal of Project Management, Vol. 22 No. 3, pp. 183-191.

Sreedharan, V.R. and Raju, R. (2016), "A systematic literature review of Lean Six Sigma in different industries", International Journal of Lean Six Sigma, Vol. 7 No. 4, pp. 430-466.

Stuart, I., McCutcheon, D., Handfield, R., McLachlin, R. and Samson, D. (2002), "Effective case research in operations management. A process perspective", Journal of Operations Management, Vol. 20 No. 5, pp. 419-433.

Suarez Barraza, M.F., Smith, T. and Dahlgaard-Park, S.M. (2009), "Lean-kaizen public service. An empirical approach in Spanish local governments", The TQM Journal, Vol. 21 No. 2, pp. 143-167.

Suresh, S., Antony, J., Kumar, M. and Douglas, A. (2012), "Six Sigma and leadership. Some observations and agenda for future research", The TQM Journal, Vol. 24 No. 3, pp. 231-247.

Susman, G.I. and Evered, R.D. (1978), "An Assessment of the Scientific Merits of Action Research", Administrative Science Quarterly, Vol. 23 No. 4, p. 582.

Svensson, C., Antony, J., Ba-Essa, M., Bakhsh, M. and Albliwi, S. (2015), “A Lean Six Sigma program in higher education", International Journal of Quality \& Reliability Management, Vol. 32 No. 9, pp. 951-969.

Swink, M. and Jacobs, B.W. (2012), "Six Sigma adoption. Operating performance impacts and contextual drivers of success", Journal of Operations Management, Vol. 30 No. 6, pp. 437-453.

Swiss, J.E. (1992), “Adapting Total Quality Management (TQM) to Government”, Public Administration Review, Vol. 52 No. 4, p. 356.

Taner, M.T., Sezen, B. and Antony, J. (2007), "An overview of six sigma applications in healthcare industry”, International Journal of Health Care Quality Assurance, Vol. 20 No. 4, pp. 329-340.

Thomas, A.J., Antony, J., Francis, M. and Fisher, R. (2015), “A comparative study of Lean implementation in higher and further education institutions in the UK", International Journal of Quality \& Reliability Management, Vol. 32 No. 9, pp. 982-996.

Thürer, M., Tomašević, I. and Stevenson, M. (2017), "On the meaning of 'Waste'. Review and definition", Production Planning \& Control, Vol. 28 No. 3, pp. 244-255.

Valle, M. (1999), "Crisis, Culture and Charisma. The New Leader's Work in Public Organizations", Public Personnel Management, Vol. 28 No. 2, pp. 245-257.

van der Hoorn, B. (2016), "Discussing project status with the project-space model. An action research study", International Journal of Project Management, Vol. 34 No. 8, pp. 1638-1657.

Voss, C., Tsikriktsis, N. and Frohlich, M. (2002), "Case research in operations management", International Journal of Operations \& Production Management, Vol. 22 No. 2, pp. 195-219.

Wells, P. and Nieuwenhuis, P. (2017), "Operationalizing Deep Structural Sustainability in Business. Longitudinal Immersion as Extensive Engaged Scholarship", British Journal of Management, Vol. 28 No. 1, pp. 45-63.

Wicks, P.G. and Reason, P. (2009), "Initiating action research. Challenges and paradoxes of opening communicative space”, Action Research, Vol. 7 No. 3, pp. 243-262.

Winter, M., Smith, C., Morris, P. and Cicmil, S. (2006), "Directions for future research in project management. The main findings of a UK government-funded research network", International Journal of Project Management, Vol. 24 No. 8, pp. 638-649. 
Authors' post-print manuscript. DOI 10.1108/IJLSS-02-2017-0019.

Wollmann, H. (2004), "Local Government Reforms in Great Britain, Sweden, Germany and France. Between Multi-Function and Single-Purpose Organisations", Local Government Studies, Vol. 30 No. 4, pp. 639-665.

Womack, J.P. and Jones, D.T. (2003), Lean thinking: Banish waste and create wealth in your corporation, Free Press, New York.

Womack, J.P., Jones, D.T. and Roos, D. (1991), The machine that changed the world: How Japan's secret weapon in the global auto wars will revolutionize western industry, Harper Perennial, New York.

$\mathrm{Zu}$, X., Fredendall, L.D. and Douglas, T.J. (2008), "The evolving theory of quality management. The role of Six Sigma", Journal of Operations Management, Vol. 26 No. 5, pp. 630-650. 